

Report Number: JIEE 2001-01

\begin{abstract}
ASSESSMENT OF THE POTENTIAL TO
REDUCE EMISSIONS FROM ROAD

TRANSPORTATION, NOTABLY NOX, THROUGH THE USE OF ALTERNATIVE VEHICLES AND FUELS IN THE GREAT SMOKY MOUNTAINS REGION
\end{abstract}

John Sheffield, JIEE/Oak Ridge National Laboratory, Coordinator

Wayne Davis, The University of Tennessee

Dejim Lowe, Tennessee Valley Authority

Timothy Lett, Knoxville Area Transit

Ralph McGill, Oak Ridge National Laboratory

This research was sponsored by the States Partnership

Program of the Office of Energy Efficiency and

Renewable Energies, U. S. Department of Energy, under contract DE-AC05-00OR22725, with UT-Battelle, LLC.

\title{
August 2001
}

Joint Institute for Energy and Environment 314 Conference Center Building

Knoxville, TN 37996-4138

Phone: (865) 974-3939

Fax: (865) 974-4609

URL: www.jiee.org

e-mail: jiee@utk.edu 


\section{TABLE OF CONTENTS}



1.1 The Problem of Air Pollution ................................................................ 1

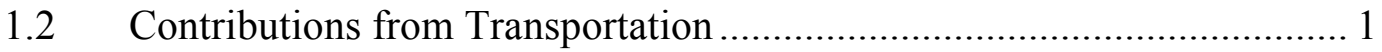

1.3 Road Transportation is Increasing ........................................................ 1

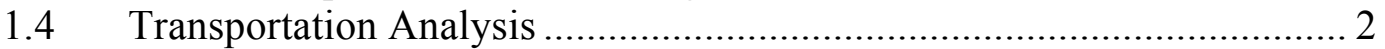

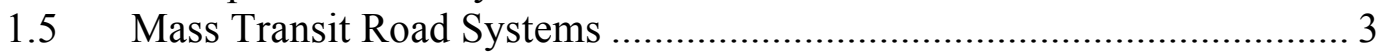

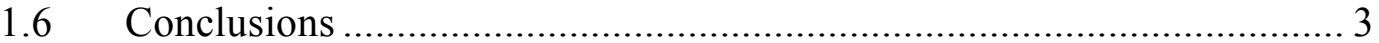

2.0 VECHCLE AND FUEL IMPROVEMENT PROGRAMS ............................... 5

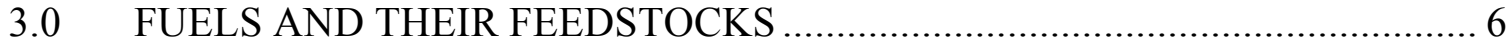





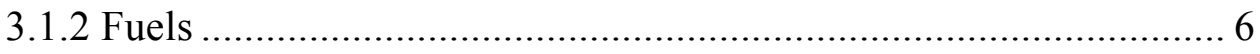

3.1.3 Reformulated gasoline.............................................................. 7

3.1.4 Fuels produced inside or outside our region..................................... 7

4.0 PASSENGER VEHICLES AND LIGHT TRUCKS ......................................... 8

4.1 Partnership for a New Generation of Vehicles (PNGV) ............................ 8

4.2 EPA Vehicle Emission Rules for Passenger Vehicles and Light Trucks ... 9

4.3 Passenger Vehicles_-Some Fuel/Vehicle Options ................................... 10

4.3.1 Near-term passenger vehicles ..................................................... 10

4.3.2 Long-term passenger vehicles ..................................................... 12

4.3.3 Near-term light duty trucks........................................................ 12

4.3.4 Long-term light duty trucks ....................................................... 14

5.0 HEAVY DUTY TRUCKS AND BUSES ..................................................... 15

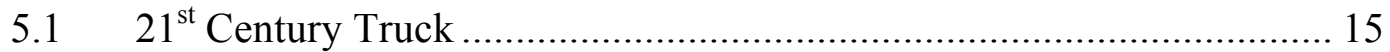

5.2 EPA Vehicle Emission Rules for Heavy Duty Trucks and Buses............ 16

5.3 Comparison of Bus Emissions with Alternative Fuels ............................ 17

5.4 Benefits of Replacing Private Passsenger Vehicles with Buses................ 18

5.4.1 Why buses? ............................................................................. 18

5.4.2 Emissions data for buses ........................................................ 18

5.4.3 Conditions for obtaining emissions reductions from using buses ... 19

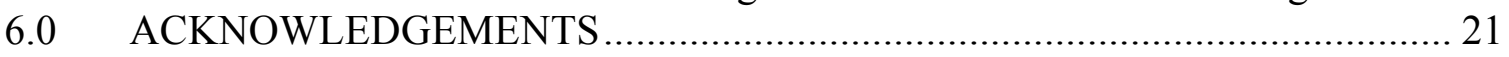

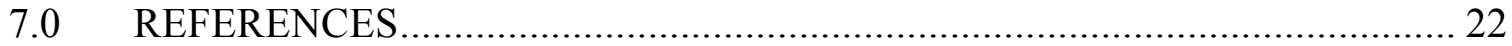




\subsection{OVERVIEW}

\subsection{The Problem of Air Pollution}

Air pollution is a serious problem in the region of the Great Smoky Mountains. The U.S. Environmental Protection Agency (EPA) may designate non-attainment areas by 2003 for ozone. Pollutants include nitrogen oxides (NOx), sulfur dioxide $\left(\mathrm{SO}_{2}\right)$, carbon monoxide (CO), volatile organic compounds (VOCs), lead, and particulate matter (PM), which are health hazards, damage the environment, and limit visibility.

The main contributors to this pollution are industry, transportation, and utilities. Reductions from all contributors are needed to correct this problem. While improvements are projected in each sector over the next decades, the May 2000 Interim Report issued by the Southern Appalachian Mountains Initiative (SAMI) suggests that the percentage of NOx emissions from transportation may increase.

\subsection{Contributions from Transportation}

Transportation, mainly motor vehicles, is already a major contributor to NOx emissions, with an estimated $32 \%$ in the (SAMI) region, and even $60 \%$ in some urban areas. NOx leads to the production of ozone and acid deposition, a health problem. In contrast, the sulfur dioxide contribution from transportation is small, a few percent. Nevertheless, reducing the sulfur content of fuels is also worthwhile not only to reduce $\mathrm{SO}_{2}$, but to improve the effectiveness of catalysts used to reduce NOx.

In fact, much of the air pollution comes from outside the Great Smoky Mountain Region. Therefore, reducing local pollution is only a partial solution to the problems. However, as an example, across the country NOx emissions from transportation are in the range $30-40 \%$ of the total emissions and our area, along with neighboring ones, will have to achieve reductions to meet ozone goals. Furthermore, transportation vehicle miles are projected to increase substantially in this region over the next decades. Consequently, both local and distant transportation will become a bigger contributor to future air pollution if actions are not taken. The new EPA rules will help achieve the needed reductions.

\subsection{Road Transportation is Increasing}

Improving the transportation situation will be a complex undertaking, requiring the achievement of multiple objectives. Our society has become accustomed to the convenience of using private vehicles for the majority of local travel and much of tourist travel. Our local transportation system has evolved to diminish the contributions of mass transit systems. This evolution, and the increases in population, vehicle ownership, and annual vehicle miles driven has led to an increasing level of pollution from transportation, which is projected to increase further. Estimates by SAMI are that vehicle miles in the region will continue to increase in the period 2000 to 2040 at the rate experienced from 1990 to 2000 , i.e., $2.5 \%$ per year. Other estimates (by The University of Tennessee) put the rate of increase at $4.2 \%$ for our region, consistent with previous experience. Substantial reductions in emissions per 
passenger (vehicle) mile may be required to meet emission reductions for Nox, VOCs, and other pollutants.

Fortunately, there are a number of ways to meet this goal, and all will be needed. One challenge is to develop, over the next decades, a transportation system that effectively combines the flexibility and convenience of both personal vehicles and mass transit systems. Contributing opportunities include:

- More fuel efficient, less polluting vehicles and fuels;

- Modern mass transit systems, both bus and rail; and

- Intelligent transport systems to minimize waste and reduce pollution.

The tightening EPA rules for vehicle emissions will play an important part in meeting goals, because many of the vehicles contributing to local pollution are using the interstate highway system. Therefore, it will be important to have vehicle testing to ensure that emission standards are being met.

\subsection{Transportation Analysis}

Analyses of the potential changes in emissions from transportation in East Tennessee, over the next 30 years, have been made at the University of Tennessee. The reports consider both the past and future trends in vehicle miles and the effect of implementation of the stricter EPA emission rules coming in over the next decade. If the past trends in vehicle miles per year continue ( $4.2 \%$ increase per year), the NOx emissions will drop, owing to stricter regulations, to about $30 \%$ of today's level and then start increasing. The VOC emissions will drop to about 50\% and then increase. These points are illustrated in Figures 1 and 2 (Davis, et al). Obviously, lower rates of increase in vehicle miles per year would improve the situation. The calculations were made assuming a $4.2 \%$ annual growth rate in Tennessee for vehicle miles, compensated for by implementation of new EPA emission standards. These include the National Low Emission Vehicle (NLEV) Standards for Light-Duty GasolineFueled Vehicles, the 2004 NOx Standards for Heavy-Duty Diesel Engines (HDDVNOx), the Tier 2/Sulfur Standards, and diesel sulfur rule. EPA's MOBILE6 model was used with a Reid Vapor Pressure (RVP) of 9.0 for the fuel. Both refueling and evaporative emissions were included in the VOC emissions.

The expectation of vehicle research and development programs is that the technologies exist, or could be developed, to realize the kind of improvements required by the EPA. In fact, an optimistic view is that even lower polluting vehicles can be developed. Clearly, there are a number of issues:

- If developed, will the vehicles be marketed?

- If marketed, will they be purchased? And at what rate?

- Will the infrastructure be in place to support them?

- Will testing be done to ensure that vehicles are performing correctly? 
Some of these questions cannot be answered locally, but some can. Do local taxes on vehicles reflect their emission characteristics? Is there local and state support, in addition to federal support, for installing the infrastructure? Will there be emissions testing as in other states?

\subsection{Mass Transit Road Systems}

Even if all these issues are dealt with, it seems likely that improved mass transit systems will be needed to lower emissions in a time of increasing passenger miles. The congested traffic conditions to be found in the Sevierville-Gatlinburg corridor and in parts of the Great Smoky Mountains National Park highlight a broader need to introduce improved mass transit systems.

This area as a whole can learn from the success of enhanced bus services in Chattanooga. In general, the use of buses will make sense when the emissions per passenger mile are less than from the use of individual vehicles to perform the same service. This is more likely to be the case when the passenger vehicles are making a series of short trips, e.g., from one shopping area to another. The improvement is most marked when the bus is a modern low-emission vehicle.

\subsection{Conclusions}

- It is essential to consider the entire fuel cycle in assessing the benefits, or disadvantages, of an alternative fuel option, i.e., feedstock and fuel production, in addition to vehicle operation!

- Many improvements to the energy efficiency of a particular vehicle and engine combination will also reduce emissions by reducing fuel use, e.g., engine efficiency, reduced weight, drag and tire friction, and regenerative braking.

- In reducing emissions it will be important to install the infrastructure to provide the improved fuels, support the maintenance of advanced vehicles, and provide emissions testing of both local vehicles and those from out of state.

- Public transit systems using lower emission vehicles can play an important role in reducing emissions per passenger mile by carrying passengers more efficiently, particularly in congested areas. However, analysis is required for each situation!

- Any reduction in emissions will be welcome, but the problems of air pollution in our region will not be solved by a few modest improvements. Substantial reductions in emissions of key pollutants are required both in East Tennessee and in neighboring areas. 
Figure 1-Effect of regulations on VOC emissions, 4.2\% constant growth rate transportation scenario (courtesy W. Davis, University of Tennessee).

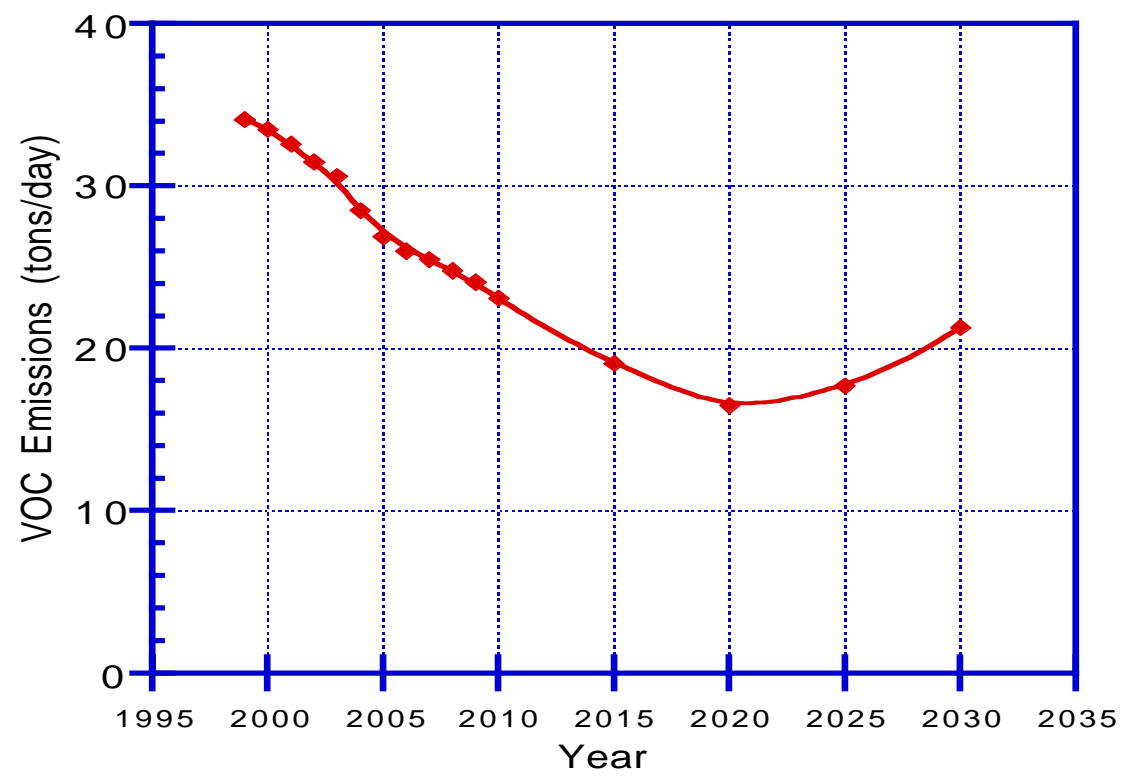

Figure 2-Effect of regulations on NOx emissions, $4.2 \%$ constant growth rate transportation scenario (courtesy W. Davis, University of Tennessee).

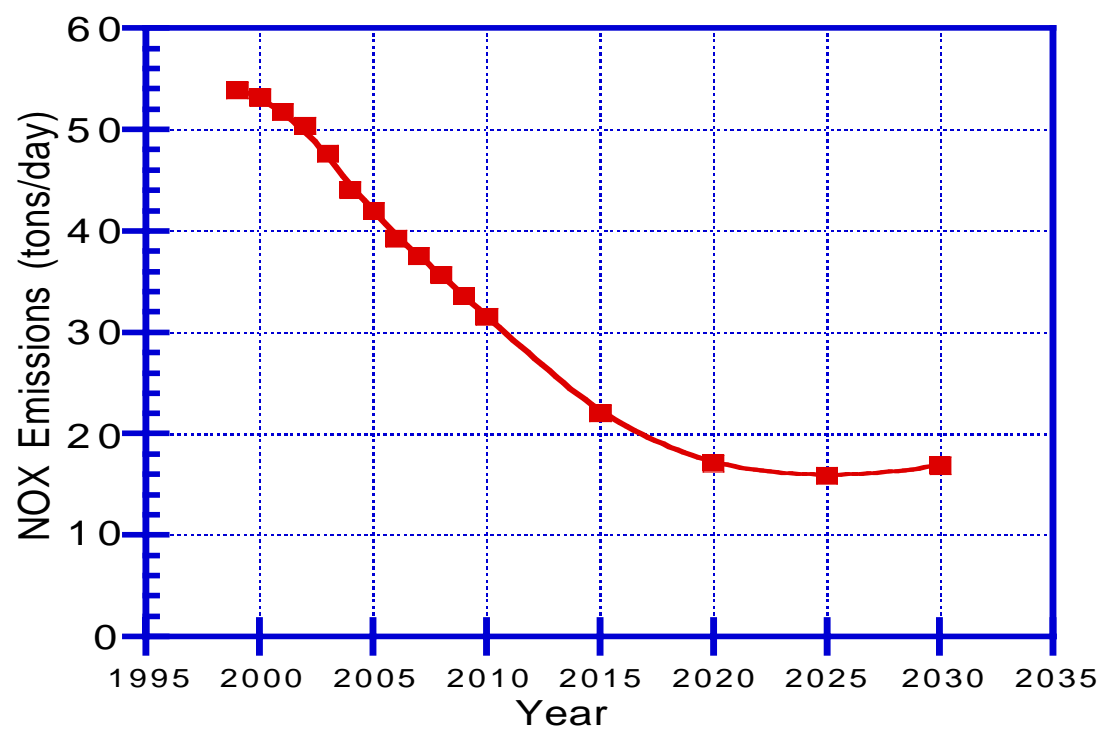




\subsection{VEHICLE AND FUEL IMPROVEMENT PROGRAMS}

There are three parallel approaches being followed to reduce emissions, as follows:

- The vehicle manufacturers are working with the Departments of Commerce, Defense, Energy, and Transportation (DOC, DOE, DOD, DOT) to develop technologies and vehicles that will have much greater fuel efficiency and lower emissions. These programs are the Partnership for a New Generation of Vehicles (PNGV), and the 21st Century Truck.

- The DOE also has programs to develop alternative fuels such as ethanol from biomass, and hydrogen from a variety of sources with its supporting infrastructure.

- In parallel, the EPA is tightening the rules on emissions from vehicles, thereby encouraging the development of improvements in fuels and vehicles.

The Corporate Average Fuel Economy (CAFE) standards for fuel economy of passenger vehicles, initiated in 1978, led to a steady improvement in domestically produced passenger fleet efficiency (18.7 mpg to $26.9 \mathrm{mpg}$ ) until 1990, at which time no further improvements were mandated. In the past decade or so there has been a switch from automobiles (average fuel economy about $28 \mathrm{mpg}$ ) to pickup trucks, minivans, and sports utility vehicles of lower efficiency (average about $20 \mathrm{mpg}$ ). As a result, the average fleet efficiency has declined from $26.2 \mathrm{mpg}$ in 1987 to $24.5 \mathrm{mpg}$ in 1999 (Transportation Energy Data Book, Edition 20, October 2000). 


\subsection{FUELS AND THEIR FEEDSTOCKS}

A comprehensive discussion and computer analysis of the emission characteristics of a variety of fuels and passenger vehicles has been made by Wang (1999). A summary of key points about fuel cycles from this report and other sources is given below. Similar results for full fuel cycle and vehicle emissions were reported in an International Energy Agency (IEA) document "Comparison of Relative Environmental Impacts of Alternative and Conventional Motor Fuels," September 1995.

\subsection{Complete Fuel Cycle}

\subsubsection{Feedstocks}

Possible feedstocks for transportation fuels include:

- Petroleum;

- Natural Gas;

- Coal;

- Biomass (corn, soybeans, herbaceous and woody biomass); and

- Electricity (generated from fossil, nuclear, geothermal, and solar energies, hydropower, and wind power).

\subsubsection{Fuels}

Fuels produced from these feedstocks include:

- Conventional gasoline (CG), reformulated gasoline (FRFG), conventional diesel (CD), reformulated diesel (RFD), liquid petroleum gas (LPG, mainly propane);

- Natural gas (methane), methanol, dimethyl ether, diesel by the Fischer-Tropsch process;

- Ethanol (generally from biomass) and biodiesel;

- Hydrogen from fossil fuels (usually natural gas), electricity, and biomass; and

- Electricity.

In the comparisons of different fuels presented below, the alternative fuels are compared to gasoline in the near term and to reformulated gasoline in the long-term (2010 and beyond).

Inspection of the comprehensive results presented by Wang (1999) indicates that among the best fuels for our region will be:

- Reformulated gasoline Phase 2, FRFG2;

- Reformulated diesel;

- Compressed natural gas (CNG) (methanol, from natural gas, has similar emissions), and hydrogen from natural gas; 
- Electricity and hydrogen from electricity, when the source of electricity has low emissions; and

- Ethanol and other biofuels when the full fuel cycle is improved.

In the longer term, as cheaper oil is depleted, liquid fuels produced from coal and gas (Fischer-Tropsch process) can become more important in the region.

\subsubsection{Reformulated gasoline}

The reformulated fuels have lower sulfur content, consistent with the tightening EPA rules, and lead to lower SOx emissions. The reformulated gasoline contains oxygenates, such as methyl tertiary butyl ether (MTBE), ethyl tertiary butyl ether (ETBE), and ethanol (EtOH), that help reduce $\mathrm{CO}$ in winter and reduce air toxics and ozone precursors in summer. Compared to conventional gasoline, the Phase 2 version (FRFG2) will lead to 26\% lower VOC emissions in the north and $27.5 \%$ less in the south, reduce air toxics by $20 \%$, and NOx by $3 \%$. MBTE is specified in the federally specified reformulated gasoline. However, MTBE is being phased out in California and the EPA is considering banning it, so it is probable that a different oxygenate will be used in the future. Therefore, the MTBE version will be used below as a benchmark for the near term and an ethanol-oxygenated reformulated gasoline for the long term.

\subsubsection{Fuels produced inside or outside our region}

Large total fuel cycle emissions can make an otherwise attractive fuel unattractive if it is produced in our region. Therefore, it is important to consider those fuels that are produced outside the region separately from those that are produced, or might be produced, locally, e.g., ethanol and electricity.

For fuels that presently have large non-vehicle emissions for their fuel cycles, and might be produced locally, it is important to find ways to reduce their non-vehicle emissions. For example, electrically powered vehicles have the lowest vehicle emissions. However, if they are powered by electricity produced from a range of sources typical of the U.S. mix (55\% coal generated), their complete fuel cycle emissions of NOx and SOx are higher than for conventional gasoline, let alone reformulated gasoline. The contributions to electricity from hydropower and nuclear power prevent the situation from being worse. A solution is to provide electricity from dedicated low emission sources. In the longer term, the emissions from the U.S. electricity mix are expected to decrease and this problem will be lessened, e.g., through the increased use of natural gas to produce electricity and the development of coal plants with very low emissions.

Production of biomass feedstock for ethanol leads to emissions of NOx, etc., because of the use of nitrate fertilizers and tractors and trucks for harvesting and transportation. Production of ethanol involves the combustion of fuels in air, e.g., coal and gas, which leads to further emissions. Improved production could be achieved by using advanced vehicles meeting Tier 2 emission standards for biomass harvesting, lower emission processes for production, and from capturing, lowering, and/or converting the NOx produced. 


\subsection{PASSENGER VEHICLES AND LIGHT TRUCKS}

This categories of vehicles includes:

- LDV - Light Duty Vehicle for passengers $\leq 12$ seats.

- LLDT - Light Duty Trucks with gross vehicle weight up to 6,000 lbs. Includes LDT1 and LDT2.

- HLDT-Heavy LDT of more than 6,000 lbs. Includes LDT3 and LDT4.

- MDPV-Heavy Duty Passenger Vehicle at up to 10,000 lbs.

It is the combination of fuel and vehicle that determines the total emissions, and considerable advances have been and are being made in improving vehicles. The important areas for further improvement are:

- Vehicle efficiency, which depends upon:

$\circ$ Engine efficiency;

- Transmission/drive efficiency;

- Aerodynamics:

- Reduced tire friction;

- Less power for auxiliary systems;

$\circ$ Weight reductions;

$\circ$ Use of regenerative braking; and

- Emissions controls:

○ Lower engine emissions;

- Catalytic converters; and

- Filters.

Both spark-ignited (SI) and compression-ignited (CI) internal combustion engines are being improved. Further improvements may be obtained by using them in hybrid-electric vehicles, because the engine may be sized down to meet more nearly constant operating conditions. The surges of power are being provided by the electrical storage. A further gain can come from the use of regenerative braking to return kinetic energy to the storage system. This is one approach being considered by the PNGV (below) to improve fuel consumption by three times.

Electrically powered vehicles can have high efficiency, but in their pure grid-supplied form they are limited by the weight of present storage systems, and need a supply of electricity from a clean source, as discussed above. In contrast, fuel-cell-powered vehicles using hydrogen and oxygen (air) are not limited by fuel storage if a fossil fuel is used with an on-board reformer to make hydrogen. However, some further progress is required to improve hydrogen storage if it is the fuel. Higher temperature fuel cells, using fossil fuels directly, may be a future option.

\subsection{Partnership for a New Generation of Vehicles (PNGV)}

The PNGV involves a partnership of government departments and the three major automobile manufacturers - Chrysler, Ford, and General Motors. 
The three goals of the PNGV are to:

- Significantly improve national competitiveness in manufacturing.

- Implement commercially viable innovation from ongoing research on conventional vehicles. Pursue advances in vehicles that can lead to improvements in the fuel efficiency and emissions of standard vehicle designs while pursuing safety advances to maintain safety performance.

- Develop a vehicle to achieve up to three the fuel efficiency of today's comparable vehicle (i.e., Chrysler Concorde, Ford Taurus, and Chevrolet Lumina) with equivalent customer purchase price of today's comparable sedans adjusted for economics.

The fuel efficiency goal corresponds to about $80 \mathrm{mpg}$. A diesel vehicle has already achieved this level. In addition, two hybrid-electric vehicles with good fuel economy are now testing in the marketplace - the Honda Insight (64 mpg) and the Toyota Prius (56 mpg). The vehicles are being designed to meet the EPA Tier 2 emission standards at the default levels of 0.2 grams/mile NOx, 0.125 grams/mile hydrocarbons, and 1.7 grams/mile CO at 100,000 miles while complying with other Clean Air Act requirements.

\subsection{EPA Vehicle Emission Rules for Passenger Vehicles and Light Trucks}

Table 4.1-EPA Motor Vehicle Emission Standards: passenger cars, light trucks, SUVs, vans, and minivans operated on any fuels + gasoline sulfur requirements (grams/mile [g/mile])

\begin{tabular}{|l|lr|r|r|}
\hline \multicolumn{1}{|c|}{ Year } & \multicolumn{2}{|c|}{$\begin{array}{c}\text { NOx } \\
\text { (g/mile) }\end{array}$} & $\begin{array}{l}\text { NMOG/ } \\
\text { (NMHC) } \\
\text { (g/mile) }\end{array}$ & \multicolumn{1}{c|}{$\begin{array}{c}\text { PM } \\
\text { (g/mile) }\end{array}$} \\
\hline Federal Emissions & \multicolumn{1}{|c|}{ LDV } & .40 & 0.25 & 0.08 \\
Control Requirements & LLDT & $0.4 / 1.2$ & & \\
1995-on & HLDT & No Rule & & \\
\hline National Low & LDV, LDT1 & 0.30 & 0.075 & \\
Emission Vehicle & LDT2 & 0.50 & 0.10 & \\
Standard (NLEV) & HLDT & No Rule & & \\
\hline New Standard $*$ & LDV, LLDT & 0.07 & 0.09 & \\
from 2004-2007 & \multicolumn{2}{|c|}{0.01} \\
from 2008-2009 & HLDT, MDPV & 0.07 & & \\
\hline
\end{tabular}

* In addition, reduced sulfur content in gasoline from the current average of about $330 \mathrm{ppm}$ to $120 \mathrm{ppm}$ (300 ppm cap) by 2004, and to $30 \mathrm{ppm}$ ( $80 \mathrm{ppm}$ cap) by 2006. The EPA estimates VOCs reductions of $7 \%$ by 2007 and $17 \%$ by 2020 through this program.

NLEV - National Low Emission Vehicle, a voluntary standard. NMOG-Non-Methane Organic Gases, similar to NMHC.

For the record, the estimated average emissions for the passenger fleet in 2000, calculated using the MOBILE5b model is $1.54 \mathrm{~g} / \mathrm{mile}$ for Nox (see Table 5.6). This much higher value 
reflects in part the presence of many older vehicles and an increasing use of pickup trucks, minivans, and SUVs.

\subsection{Passenger Vehicles-Some Fuel/Vehicle Options}

A comparison of emission characteristics for gasoline powered LDVs is given in Table 4.2. The computed emission values come from the excellent report of M. Wang (1999). We emphasize that the emission values are computed and the relative values of emissions for different combinations of engines and fuels have the decided advantage of being calculated self-consistently. However, actual data from tests on particular vehicles may differ, and the performance of some of today's vehicles may be better than the examples given. A similar assessment was made by the IEA (1995).

The examples are: a near-term passenger vehicle of today, powered by conventional gasoline and also by Federal Phase 2, Reformulated Gasoline (FRFG2) with MTBE oxygenator, and a long-term passenger car using FRFG2 with EtOh and meeting EPA's Tier 2 emission standards. The emission numbers quoted are for the vehicle use only, except that total fuel cycle emissions of NOx are also given.

\subsubsection{Near-term passenger vehicles}

Table 4.2-Emission characteristics of some gasoline powered passenger vehicles (Wang 1999)

\begin{tabular}{|c|c|c|c|c|}
\hline \multirow[t]{2}{*}{$\begin{array}{c}\text { Emissions } \\
\text { (Vehicle only) }\end{array}$} & \multicolumn{2}{|c|}{$\begin{array}{c}\text { Near-term LDV } \\
\text { Conventional } \\
\text { Gasoline }\end{array}$} & \multirow[t]{2}{*}{$\begin{array}{c}\text { Near-term LDV } \\
\text { FRFG2 MTBE } \\
\text { Normalized }\end{array}$} & \multirow[t]{2}{*}{$\begin{array}{c}\text { Long-term SIDI } \\
\text { FRFG2 EtOH } \\
\text { Normalized }\end{array}$} \\
\hline & g/mile & Normalized & & \\
\hline VOCs & 0.207 & 1.00 & 0.78 & 0.60 \\
\hline $\mathrm{CO}$ & 5.517 & 1.00 & 0.80 & 0.50 \\
\hline PM10 & 0.033 & 1.00 & 0.97 & 1.09 \\
\hline SOx & 0.050 & 1.00 & 0.16 & 0.12 \\
\hline $\mathrm{CH} 4$ & 0.084 & 1.00 & 0.92 & 0.85 \\
\hline $\mathrm{NOx}$ & 0.275 & 1.00 & 0.95 & 0.13 \\
\hline NOx total fuel cycle & 0.473 & 1.00 & 1.00 & $* 0.38$ \\
\hline
\end{tabular}

The emissions in grams per mile are given for the reference fuel and vehicle, in this case the near-term LDV using conventional gasoline. For the other fuels, the emissions are normalized to the reference case, i.e., VOC emissions for a near-term LDV are $0.78 \mathrm{x}$ $0.207=0.161 \mathrm{~g} / \mathrm{mile}$.

The improved fuel and long-term LDV lead to lower emissions of VOCs and CO. The bold numbers highlight significant improvements (less than $50 \%$ of the emissions) over the conventional gasoline case. In this example they show that the reduction in sulfur content leads to lower SOx emissions. It also reduces degradation of the catalysts used to reduce NOx emissions, permitting a much higher catalytic conversion of NOx. 


\begin{tabular}{|c|c|c|c|c|c|c|}
\hline \multirow{2}{*}{$\begin{array}{c}\text { Emissions } \\
\text { Vehicle } \\
\text { only }\end{array}$} & \multicolumn{2}{|c|}{$\begin{array}{l}\text { Near-term LDV } \\
\text { FRFG2 MTBE } \\
\end{array}$} & \multirow{2}{*}{$\begin{array}{c}\text { Compresse } \\
\text { d Natural } \\
\text { Gas Vehicle } \\
\text { Normalized }\end{array}$} & \multirow{2}{*}{\begin{tabular}{|c|} 
Liquid \\
Petroleum \\
Gas Vehicle \\
Normalized
\end{tabular}} & \multirow{2}{*}{\begin{tabular}{|c} 
Ethanol E-85 \\
Flexible Fuel \\
Vehicle \\
Normalized
\end{tabular}} & \multirow{2}{*}{$\begin{array}{c}\text { Electric } \\
\text { Vehicle US } \\
\text { electric mix } \\
\text { Normalized }\end{array}$} \\
\hline & g/mile & Normalized & & & & \\
\hline VOCs & 0.161 & 1.00 & 0.28 & 0.48 & 1.09 & $\mathbf{0}$ \\
\hline $\mathrm{CO}$ & 4.414 & 1.00 & 0.70 & 0.75 & 0.75 & $\mathbf{0}$ \\
\hline PM10 & 0.032 & 1.00 & 0.69 & 0.69 & 0.81 & 0.66 \\
\hline $\mathrm{SOx}$ & 0.008 & 1.00 & 0.25 & $\mathbf{0}$ & 1.25 & $\mathbf{0}$ \\
\hline $\mathrm{CH} 4$ & 0.077 & 1.00 & 10.9 & 1.42 & 1.64 & $\mathbf{0}$ \\
\hline $\mathrm{NOx}$ & 0.261 & 1.00 & 0.95 & 0.95 & 0.95 & $\mathbf{0}$ \\
\hline $\begin{array}{l}\text { NOx Total } \\
\text { fuel cycle }\end{array}$ & 0.474 & 1.00 & 1.19 & 0.82 & 2.01 & 1.64 \\
\hline
\end{tabular}

The need to consider the whole fuel cycle is illustrated by the much smaller decrease in NOx emissions for the total fuel cycle. This is a crucial point when considering other fuel/vehicle combinations, as shown in Table 4.3.

The bold italicized numbers highlight emissions that are significantly worse than the reference reformulated gasoline case.

In terms of NOx emissions, none of these options is better than reformulated gasoline when the total fuel cycle is considered. In fact, if the fuels are produced locally, today's ethanol option and electric vehicle option (US electricity mix) are substantially worse. As discussed above, it would be a good idea to develop lower emission production for these fuels.

Natural gas vehicles have advantages in regard to lower VOCs, PM10 and SOx emissions, but their total fuel cycle has large methane emissions. Per unit amount, methane has a much larger greenhouse gas effect than carbon dioxide. Nevertheless, in terms of total green house gas effects, the methane contribution is much less than the carbon dioxide contribution. 


\subsubsection{Long-term passenger vehicles}

Table 4.4 - The emission characteristics of some long-term passenger vehicles and fuels, meeting Tier 2 standards (Wang, 1999).

\begin{tabular}{|c|c|c|c|c|c|c|}
\hline \multirow[t]{2}{*}{$\begin{array}{c}\text { Emissions } \\
\text { Vehicle only } \\
\text { (g/mile) }\end{array}$} & \multicolumn{2}{|c|}{$\begin{array}{c}\text { Long-term } \\
\text { SIDI FRFG2 } \\
\text { EtOH }\end{array}$} & \multirow{2}{*}{$\begin{array}{l}\text { Ethanol } \\
\text { E-90 } \\
\text { Biomass } \\
\text { Normalized }\end{array}$} & \multirow{2}{*}{$\begin{array}{l}\text { HEV, SIDI } \\
\text { US mix } \\
\text { elec. } \\
\text { FRFG2/ } \\
\text { EtOH } \\
\text { Normalized }\end{array}$} & \multirow{2}{*}{$\begin{array}{c}\text { Electric } \\
\text { Vehicle } \\
\text { US elec. } \\
\text { Mix } \\
\text { Normalized }\end{array}$} & \multirow{2}{*}{$\begin{array}{c}\text { H2-FCV* } \\
\text { Natural gas } \\
\text { Refueling } \\
\text { Station } \\
\text { Normalized }\end{array}$} \\
\hline & g/mile & $\begin{array}{l}\text { Normalize } \\
\text { d }\end{array}$ & & & & \\
\hline VOCs & 0.125 & 1.00 & 1.00 & 0.63 & 0 & $\mathbf{0}$ \\
\hline $\mathrm{CO}$ & 2.759 & 1.00 & 0 & 0.70 & 0 & $\mathbf{0}$ \\
\hline PM10 & 0.036 & 1.00 & 0.75 & 0.81 & 0.58 & 0.58 \\
\hline SOx & 0.006 & 1.00 & 0.17 & 0.50 & 0 & 0 \\
\hline $\mathrm{CH} 4$ & 0.071 & 1.00 & 1.51 & 0.70 & 0 & 0 \\
\hline NOx & 0.036 & 1.00 & 1.00 & 0.69 & 0 & $\underline{0}$ \\
\hline $\begin{array}{l}\text { NOx Total } \\
\text { fuel cycle }\end{array}$ & 0.180 & 1.00 & 2.97 & 1.24 & 2.40 & 0.82 \\
\hline \multicolumn{7}{|c|}{$\begin{array}{l}\text { LDV = passenger vehicle carrying } \leq 12 \text { passengers. } \\
\text { HEV }=\text { Hybrid Electric Vehicle. } \\
\text { SIDI = Spark Ignition, Direct Injection. } \\
\text { FCV = Fuel Cell Vehicle. } \mathrm{H} 2=\text { hydrogen. } \\
\text { * Note: the H2-FCV fueled with natural gas has large } \mathrm{CH} 4 \text { emissions from the feedstock } \\
\text { and fuel cycle }-0.376 \mathrm{~g} / \mathrm{mile!}\end{array}$} \\
\hline
\end{tabular}

Wang considers a wide range of vehicle and fuel options: gasoline vehicle (GV); spark ignition, direct injection (SIDI); compression ignition, direct injection (CIDI); hybrid electric vehicle (HEV), both grid-independent and grid-connected); electric vehicle (EV); and fuel cell and liquid natural gas, liquid petroleum gas, reformulated diesel, methanol, ethanol, and hydrogen. The main variations are captured in Table 4.4 below. Again, NOx emissions from the whole fuel cycle are used to illustrate the point that it is not sufficient to consider only vehicle emissions when discussing pollution.

\subsubsection{Near-term light duty trucks}

The performance of light duty trucks follows the same patterns as passenger vehicles. In the near-term, emissions vary modestly in comparison with gasoline-fueled vehicles when the full fuel cycle is taken into account, with the exception of gains due to the use of low sulfur fuels, or electricity from clean sources.

In the long-term, when vehicles will be subject to Tier 2 emission standards, there will be further improvements. 


\begin{tabular}{|c|c|c|c|c|c|c|}
\hline \multirow{2}{*}{$\begin{array}{c}\text { Emissions } \\
\text { Vehicle only } \\
\text { (g/mile) }\end{array}$} & \multicolumn{2}{|c|}{$\begin{array}{c}\text { Conventional } \\
\text { Gasoline }\end{array}$} & \multirow{2}{*}{$\begin{array}{c}\text { FRFG2 } \\
\text { MTBE } \\
\text { Normalized }\end{array}$} & \multirow{2}{*}{$\begin{array}{c}\text { Long-term } \\
\text { SIDI } \\
\text { FRFG2 } \\
\text { EtOH } \\
\text { Normalized } \\
\end{array}$} & \multirow{2}{*}{$\begin{array}{c}\text { CIDI } \\
\text { Conventiona } \\
1 \\
\text { Diesel } \\
\text { Normalized } \\
\end{array}$} & \multirow{2}{*}{$\begin{array}{c}\text { EV } \\
\text { US mix } \\
\text { Normalize } \\
\text { d }\end{array}$} \\
\hline & g/mile & Normalized & & & & \\
\hline VOCs & 0.198 & 1.00 & 0.79 & 0.60 & 0.46 & $\mathbf{0}$ \\
\hline $\mathrm{CO}$ & 0.247 & 1.00 & 0.80 & 0.33 & 0.14 & $\mathbf{0}$ \\
\hline PM10 & 0.036 & 1.00 & 0.97 & 0.97 & 3.36 & 0.58 \\
\hline SOx & 0.066 & 1.00 & 0.15 & 0.11 & 0.16 & $\mathbf{0}$ \\
\hline $\mathrm{CH} 4$ & 0.090 & 1.00 & 0.92 & 0.79 & 0.014 & $\mathbf{0}$ \\
\hline NOx & 0.381 & 1.00 & 0.95 & 0.09 & 1.57 & $\mathbf{0}$ \\
\hline $\begin{array}{l}\text { NOx Total } \\
\text { fuel cycle }\end{array}$ & 0.645 & 1.00 & 1.00 & 0.42 & 1.18 & 1.61 \\
\hline
\end{tabular}

Table 4.6 - The emission characteristics of some near-term heavy light-duty trucks HLDT 6,001-8,500 lbs (Wang, 1999).

\begin{tabular}{|c|c|c|c|c|c|c|}
\hline \multirow{2}{*}{$\begin{array}{c}\text { Emissions } \\
\text { Vehicle only } \\
\text { (g/mile) }\end{array}$} & \multicolumn{2}{|c|}{$\begin{array}{c}\text { Conventional } \\
\text { Gasoline }\end{array}$} & \multirow{2}{*}{$\begin{array}{c}\text { FRFG2 } \\
\text { MTBE } \\
\text { Normalized }\end{array}$} & \multirow{2}{*}{$\begin{array}{c}\text { Long-term } \\
\text { SIDI } \\
\text { FRFG2 } \\
\text { EtOH } \\
\text { Normalized }\end{array}$} & \multirow{2}{*}{$\begin{array}{c}\text { CIDI } \\
\text { Conventiona } \\
\mathbf{l} \\
\text { Diesel } \\
\text { Normalized }\end{array}$} & \multirow{2}{*}{$\begin{array}{c}\text { EV } \\
\text { US mix } \\
\text { Normalize } \\
\text { d }\end{array}$} \\
\hline & g/mile & Normalized & & & & \\
\hline VOCs & 0.785 & 1.00 & 0.86 & 0.20 & 0.69 & $\mathbf{0}$ \\
\hline $\mathrm{CO}$ & 16.85 & 1.00 & 0.80 & 0.33 & $\mathbf{0 . 0 7}$ & $\mathbf{0}$ \\
\hline PM10 & 0.036 & 1.00 & 0.97 & 1.36 & 3.61 & 0.58 \\
\hline SOx & 0.078 & 1.00 & 0.15 & 0.12 & 0.96 & $\mathbf{0}$ \\
\hline $\mathrm{CH} 4$ & 0.090 & 1.00 & 0.92 & 1.01 & 0.19 & $\mathbf{0}$ \\
\hline $\mathrm{NOx}$ & 1.173 & 1.00 & 0.98 & 0.12 & 1.04 & $\mathbf{0}$ \\
\hline $\begin{array}{l}\text { NOx Total } \\
\text { fuel cycle }\end{array}$ & 1.482 & 1.00 & 0.98 & 0.24 & 0.95 & 0.82 \\
\hline
\end{tabular}




\subsubsection{Long-term light duty trucks}

Table 4.7-The emission characteristics of some long-term light light-duty trucks

LLDT $\leq 6,000 \mathrm{lbs}$ (Wang, 1999).

\begin{tabular}{|c|c|c|c|c|c|c|}
\hline \multirow{2}{*}{$\begin{array}{c}\text { Emissions } \\
\text { Vehicle only } \\
\text { (g/mile) }\end{array}$} & \multicolumn{2}{|c|}{$\begin{array}{c}\text { SIDI FRFG2 } \\
\text { EtOH }\end{array}$} & \multirow{2}{*}{$\begin{array}{c}\text { Ethanol } \\
\text { E-90 } \\
\text { Biomass } \\
\text { Normalized }\end{array}$} & \multirow{2}{*}{$\begin{array}{c}\text { HEV, } \\
\text { MBTE } \\
\text { FRFG2, } \\
\text { US elec.mix } \\
\text { Normalized }\end{array}$} & \multirow{2}{*}{$\begin{array}{c}\text { H2-FCV* } \\
\text { NG } \\
\text { Decentral. } \\
\text { Normalized }\end{array}$} & \multirow{2}{*}{$\begin{array}{c}\text { EV } \\
\text { US mix } \\
\text { Normalized }\end{array}$} \\
\hline & g/mile & Normalized & & & & \\
\hline VOCs & 0.119 & 1.00 & 1.05 & 0.62 & $\mathbf{0}$ & $\mathbf{0}$ \\
\hline $\mathrm{CO}$ & 2.759 & 1.00 & 1.00 & 0.70 & $\mathbf{0}$ & $\mathbf{0}$ \\
\hline PM10 & 0.035 & 1.00 & 2.20 & 0.83 & 0.60 & 0.60 \\
\hline SOx & 0.007 & 1.00 & 0.14 & 0.57 & $\mathbf{0}$ & $\mathbf{0}$ \\
\hline $\mathrm{CH} 4$ & 0.071 & 1.00 & 1.51 & 0.70 & $\mathbf{0}$ & $\mathbf{0}$ \\
\hline $\mathrm{NOx}$ & 0.036 & 1.00 & 1.00 & 0.69 & $\mathbf{0}$ & $\mathbf{0}$ \\
\hline $\begin{array}{l}\text { NOx Total } \\
\text { fuel cycle }\end{array}$ & 0.274 & 1.00 & 2.54 & 1.05 & 0.72 & 2.10 \\
\hline
\end{tabular}

Table 4.8 - The emission characteristics of some long-term heavy light-duty trucks HLDT 6,001 - 8,500 lbs (Wang, 1999).

\begin{tabular}{|c|c|c|c|c|c|c|}
\hline \multirow{2}{*}{$\begin{array}{c}\text { Emissions } \\
\text { Vehicle only } \\
\text { (g/mile) }\end{array}$} & \multicolumn{2}{|c|}{$\begin{array}{c}\text { SIDI FRFG2 } \\
\text { EtOH }\end{array}$} & \multirow{2}{*}{$\begin{array}{c}\text { CIDI } \\
\text { RFD } \\
\text { Normalized }\end{array}$} & \multirow{2}{*}{$\begin{array}{c}\text { HEV, } \\
\text { MBTE } \\
\text { FRFG2, } \\
\text { US elec.mix } \\
\text { Normalized }\end{array}$} & \multirow{2}{*}{$\begin{array}{c}\text { H2-FCV* } \\
\text { NG } \\
\text { Decentral. } \\
\text { Normalized }\end{array}$} & \multirow{2}{*}{$\begin{array}{c}\text { EV } \\
\text { US mix } \\
\text { Normalized }\end{array}$} \\
\hline & g/mile & Normalized & & & & \\
\hline VOCs & 0.158 & 1.00 & 0.70 & 0.59 & $\mathbf{0}$ & $\mathbf{0}$ \\
\hline $\mathrm{CO}$ & 5.518 & 1.00 & 1.00 & 0.70 & $\mathbf{0}$ & $\mathbf{0}$ \\
\hline PM10 & 0.049 & 1.00 & 0.84 & 0.78 & 0.43 & 0.43 \\
\hline SOx & 0.009 & 1.00 & 1.33 & 0.44 & $\mathbf{0}$ & $\mathbf{0}$ \\
\hline $\mathrm{CH} 4$ & 0.091 & 1.00 & 0.19 & 0.70 & $\mathbf{0}$ & $\mathbf{0}$ \\
\hline NOx & 0.135 & 1.00 & 1.33 & 0.70 & $\mathbf{0}$ & $\mathbf{0}$ \\
\hline $\begin{array}{l}\text { NOx Total } \\
\text { fuel cycle }\end{array}$ & 0.360 & 1.00 & 0.92 & 1.11 & 0.64 & 2.14 \\
\hline
\end{tabular}




\subsection{HEAVY DUTY TRUCKS AND BUSES}

\section{$5.1 \quad 21 s t$ Century Truck}

The partners in the 21st Century Truck initiative are the federal government through the DOE, DOT, DOD, EPA, OMB, in cooperation with the Office of Science and Technology Policy, and truck and bus manufacturers, their suppliers and their trade associations.

The goals of the 21st Century Truck, as described in a Technology Roadmap (Dec. 2000), are as follows:

- Improve Efficiency:

○ Double the Class 8 line-haul truck efficiency by 2010 on a ton-mile per gallon basis.

- Triple the Class $2 \mathrm{~b}$ and 6 truck (delivery van) fuel efficiency by 2010 on a ton-mile per gallon basis.

- Triple the Class 8 Transit Bus efficiency by 2010 on a ton (passenger)-mile per gallon basis.

- Reduce emissions:

- Exceed standards for oxides of nitrogen, particulate matter, carbon monoxide, and hydrocarbons for the year 2010.

- Enhance Safety

- Enhance Affordability: Maintain or Enhance Performance.

There are both goals and technical targets as shown in Table 4.1.

Table 5.1 - Fuel efficiency multiplier targets and goals for heavy trucks and buses (Technology Roadmap, December, 2000).

\begin{tabular}{|c|c|c|c|}
\hline Vehicle & Technical Target & Program Goal & "These goals are best \\
\hline Large Truck & 1.6 & 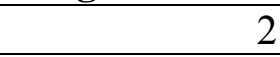 & efforts of partners. \\
\hline Transit Bus & 2.6 & 3 & There is no certainty \\
\hline Medium Truck & 2.4 & 3 & of achievement." \\
\hline Small Truck $>8,500 \mathrm{lbs}$ & $1.5-1.75$ & 3 & \\
\hline
\end{tabular}

The base fuel efficiency of a Class 8 truck — rigid and tractor-trailer-is $6.6 \mathrm{mpg}$. The technical goal is $10.3 \mathrm{mpg}$ at $65 \mathrm{mph}$, fully loaded on a level road, using diesel fuel. Such trucks consume $68 \%$ of all commercial fuel used. Improvements are expected from improved engine efficiency and lower losses in auxiliary loads, the drive train, aerodynamics, rolling resistance, and lower weight. Emissions reductions will accrue from the improved energy efficiency, but improved exhaust emission control devices to meet the new EPA standards in Table 4.2 must supplement this. The use of low sulfur fuel and advanced catalysts and filters hold the potential to meet the emission goals.

The baseline fuel efficiency for transit buses is $3.2 \mathrm{mpg}$. The technical targets are to improve the efficiency to $6 \mathrm{mpg}$ by 2004 and to $9 \mathrm{mpg}$ by 2010. The opportunities to achieve these improvements are mainly the same as for trucks, with improvements in accessory systems 
playing a larger role. The predominant choice for meeting the target is the electric-hybrid bus, which can drive all accessories electrically. In fact, electric-hybrids are particularly attractive for "stop and go" modes of operation because they allow the fossil-fueled engine to run at more nearly constant and more efficient conditions and can allow the engine size to be minimized. They can also use regenerative braking to recover energy. Such buses are being used in small numbers. The use of low sulfur fuel and advanced catalysts and filters will be important to meeting the emission goals. Fuel cell driven buses are also in development and in the early stages of demonstration.

Today's fuel efficiency for a medium truck of Class $6(19,000$ to $26,000 \mathrm{lbs})$ is $7.2 \mathrm{mpg}$ in a "stop and go" mode and $10 \mathrm{mpg}$ at a steady $40 \mathrm{mph}$. The technical goal is $24 \mathrm{mpg}$ at a steady $40 \mathrm{mph}$. This class of truck is the second largest consumer of diesel fuel. Again it is anticipated that an electric-hybrid, possibly with a reduced size (over today's engines) diesel engine, will best meet the targets. Emissions reduction requirements and solutions are similar to those for a large truck.

The base efficiency for a Class $2 \mathrm{~b}$ "pickup" truck of $>8,500 \mathrm{lbs}$ weight is $13.4 \mathrm{mpg}$. This class is used in commercial applications. The technical goal is $25.7 \mathrm{mpg}$. Again, the hybrid vehicle is a good option for dealing with transient operating conditions. The use of low sulfur fuel and advanced catalysts and filters will be important to meeting the emission goals.

\subsection{EPA Vehicle Emission Rules for Heavy Duty Trucks and Buses}

Table 5.2 - Emission standards for Highway Heavy Duty Engines in grams per brake horse power hour (g/bhp-hr): EPA: 40 CFR 9, 86 and 69, 80, 86

Diesel, etc. (for 2007-2010, to be coupled with $97 \%$ reduction in sulfur in diesel fuel)

\begin{tabular}{|c|c|c|c|}
\hline Year & $\begin{array}{c}\text { NOx } \\
(\mathrm{g} / \mathrm{bhp}-\mathrm{hr})^{*}\end{array}$ & $\begin{array}{c}\text { (NM)HC } \\
\text { (g/bhp-hr) }\end{array}$ & $\begin{array}{c}\text { PM } \\
\text { (g/bhp-hr) }\end{array}$ \\
\hline 1998 Standard & 4.0 & 1.3 & $\begin{array}{r}0.10 \text { trucks } \\
* * 0.05 \text { urban buses }\end{array}$ \\
\hline $\begin{array}{l}\text { New Standard } \\
\text { from } 2004\end{array}$ & $\begin{array}{r}2.4 \\
\text { or } 2.5\end{array}$ & $\begin{array}{r}-- \\
0.5 \text { cap NMHC }\end{array}$ & $\begin{array}{r}0.10 \text { trucks } \\
* * 0.05 \text { urban buses }\end{array}$ \\
\hline $\begin{array}{l}\text { Proposed } \\
\text { Standard } \\
2007-2010 \\
\end{array}$ & $\begin{array}{ll}\text { HD Engines } & 0.2 \\
\text { HD Vehicles } & 0.2\end{array}$ & $\begin{array}{r}0.14 \\
0.195\end{array}$ & $\begin{array}{l}0.01 \\
0.02\end{array}$ \\
\hline \multicolumn{4}{|c|}{ Gasoline } \\
\hline Current Standard & $\begin{array}{l}\leq 14,000 \mathrm{lbs} \\
>14,000 \mathrm{lbs}\end{array}$ & $\begin{array}{l}1.1 \\
1.9\end{array}$ & \\
\hline $\begin{array}{l}\text { New Standard } \\
\text { from } 2005\end{array}$ & $\begin{array}{cc}8,500-10,000 \mathrm{lbs} & 0.9 \\
10,001-14,000 \mathrm{lbs} & 1.0 \\
>14,000 \mathrm{lbs} & 1.0\end{array}$ & $\begin{array}{r}0.28 \\
0.33 \\
\text { including } \mathrm{HCs}\end{array}$ & \\
\hline
\end{tabular}




\subsection{Comparison of Bus Emissions with Alternative Fuels}

Assessments have been made of the emissions of diesel engine powered buses, using alternative fuels, in the National Renewable Energy Laboratory's "Alternative Fuel Transit Bus Evaluation Program." The tests were conducted, comparing diesel and alternative fuels, in sets of buses with the same engines. The first set of tests was completed by 1996 and tested engines built from 1988 to 1994. These tests compared CNG, ethanol, methanol, and a biodiesel blend against diesel fuel. A second set of tests of using CNG and diesel was reported in 1999. Comparisons between sets of buses were made in different parts of the country, e.g., in Atlanta, Miami, New York, and Tacoma. A summary of average results is presented in Table 5.3.

Table 5.3 - Comparison between alternative fuels and diesel of emissions (g/mile) and fuel consumption (mpg) for buses with the same types of engine

\begin{tabular}{|l|r|r|r|r|r|r|r|}
\hline \multicolumn{1}{|c|}{ Fuel } & $\begin{array}{c}\text { Engine } \\
\text { Date }\end{array}$ & $\begin{array}{c}\text { PM } \\
\text { g/mile }\end{array}$ & $\begin{array}{c}\text { NOX } \\
\text { g/mile }\end{array}$ & $\begin{array}{c}\text { HC } \\
\text { g/mile }\end{array}$ & $\begin{array}{c}\text { NMHC } \\
\text { g/mile }\end{array}$ & $\begin{array}{c}\text { CO } \\
\text { g/mile }\end{array}$ & mpg* \\
\hline $\begin{array}{l}\text { Diesel } \\
\text { Cat.Conv. }\end{array}$ & 1996 & 0.46 & 27.2 & 0.92 & 0.92 & 3.9 & 4.4 \\
\hline $\begin{array}{l}\text { CNG } \\
\text { Cat. Conv. }\end{array}$ & 1996 & 0.05 & 21.6 & 18.6 & 0.86 & 6.9 & 3.3 \\
\hline $\begin{array}{l}\text { Ratio } \\
\text { Alt/Diesel }\end{array}$ & $96 / 96$ & 0.11 & 0.79 & $* * 20.2$ & 0.93 & 1.77 & 0.75 \\
\hline $\begin{array}{l}\text { CNG } \\
\text { /Diesel }\end{array}$ & $91 / 96$ & 1.21 & 0.65 & 13.3 & & 10.1 & comparable \\
\hline Eth/Diesel & Alternative fuels normalized to diesel \\
\hline Meth/Dies & $93 / 96$ & 0.57 & 0.33 & $* * 20.2$ & & 4.2 & comparable \\
\hline $\begin{array}{l}\text { Biodiesel/ } \\
\text { Diesel }\end{array}$ & $88 / 88$ & 1.06 & 1.04 & 0.85 & & & comparable \\
\hline $\begin{array}{l}\text { 8mpg diesel equivalent for alternate fuels. } \\
* * \text { For CNG and methanol the HC is predominantly methane. }\end{array}$ \\
\hline
\end{tabular}

For compressed natural gas and methanol, emissions of particulates are significantly less, despite the lower fuel economy of CNG. Emissions of NOx and non-methane hydrocarbons are somewhat less, but hydrocarbons and $\mathrm{CO}$ are much worse. Ethanol has lower NOx emissions but it suffers worse emissions of PMs, HC, and CO. The biodiesel blend performs similarly to diesel in the 1988 engines.

However, this is not the complete picture. As in the case of the automobiles and light trucks, it is necessary to take account of emissions from the full production cycle including feedstock collection, processing and fuel production. 


\subsection{Benefits of Replacing Private Passenger Vehicles with Buses}

\subsubsection{Why buses?}

An important question for this part of the report is "How much reduction in emissions of pollutants would be associated with parking a number of private passenger vehicles and transporting the passengers by bus?"

This question is not simple to answer. The answer depends upon the number and type of passenger vehicle, the number of passengers per vehicle, the resultant number of passengers per bus, the type of bus, the type of driving cycle for each kind of vehicle, and the emissions under those cycles (urban or rural route, frequency of stops, fraction of time idling, etc.). The problem of making the analysis is compounded by the convention of defining passenger vehicle emissions in terms of g/mile while, generally, defining bus emissions in terms of $\mathrm{g} / \mathrm{bhp}$ per hour for the engine alone. In addition, to provide a complete answer would require knowing the changes in driving patterns for the remaining passenger vehicles, i.e., those not parked.

Examples are given below to indicate the kind of conditions under which emission reductions might be achieved from the use of buses.

\subsubsection{Emissions data for buses}

Fortunately, there is some data on bus emissions in $\mathrm{g} / \mathrm{mile}$ (see Tables 5.3, 5.4, and 5.5).

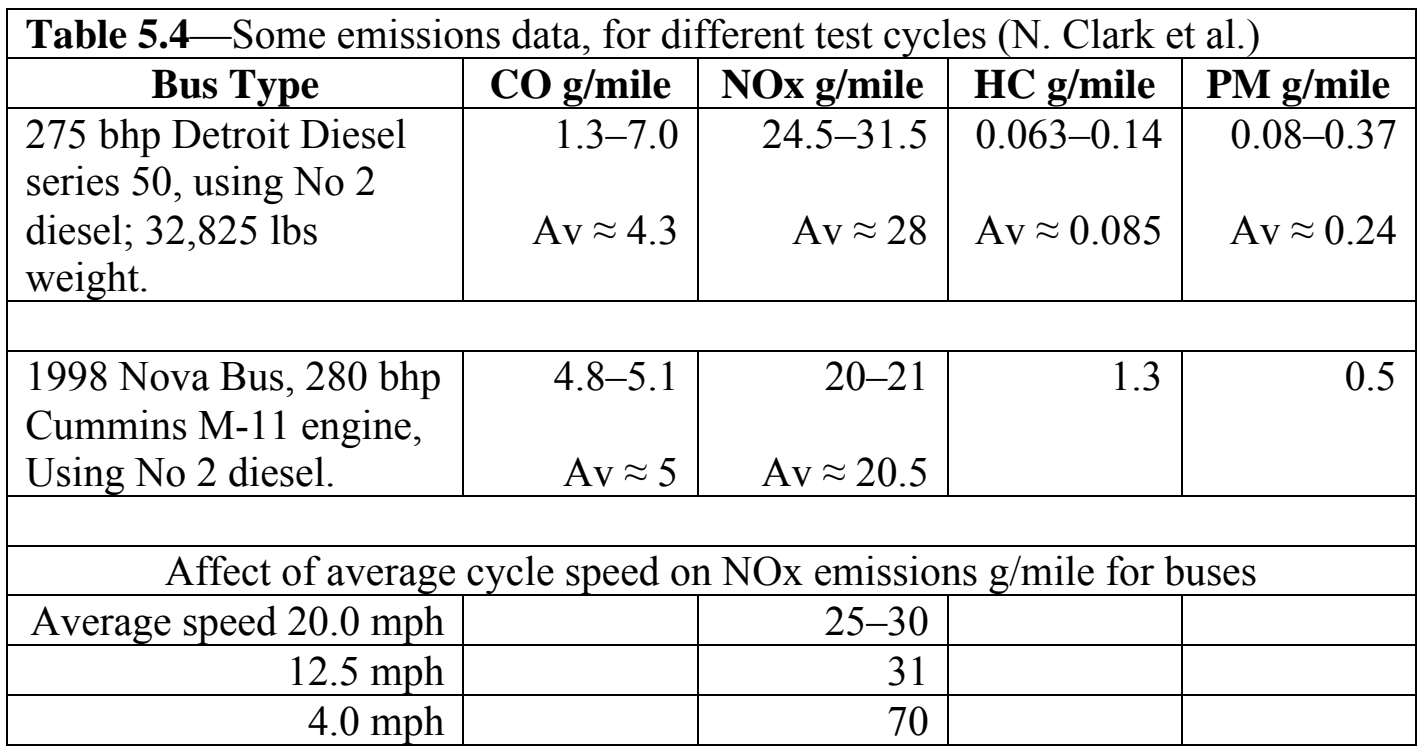

The examples in the table show the wide variability, depending on the bus and the driving cycle.

A recent study (Northeast Advanced Vehicle Consortium report) has compared the fuel economy of three kinds of buses (49-56 seaters, each with a recent model engine 1997 to 1999): 1 diesel powered bus, 2 diesel hybrid electric buses, and 3 compressed natural gas 
(CNG) powered buses. The fuels included conventional D1 distillate diesel (300 ppm sulfur), ultra-low sulfur city diesel ( $\leq 20 \mathrm{ppm}$ sulfur), a synthetic diesel with essentially no sulfur, and $\mathrm{CNG}$.

A number of driving cycles were used, with the average speed ranging from 3 to $17 \mathrm{mph}$, and with 4 to 18 stops per mile. Some key results were:

- Diesel hybrid electric buses had reduced emissions relative to conventional diesel buses, comparable to those from CNG buses, and in most cases setting the in-use benchmark. Only NOx emissions failed to set the benchmark.

- The hybrid buses were typically $65 \%$ more fuel efficient than conventional diesel buses and more than 100\% more efficient than CNG buses.

- All kinds of buses emitted less particulates with the low (zero) sulfur fuels. Hybrid emissions ranged from $0.01 \mathrm{~g} / \mathrm{mile}$ for low synthetic diesel to $0.16 \mathrm{~g} / \mathrm{mile}$ for diesel fuel.

- Carbon monoxide emissions were 70\% lower for hybrids and 30\% higher for CNG fueled buses than for the diesel bus.

- Ozone producing precursors such as NOx and non-methane organic compounds were $30-40 \%$ lower for hybrids, and 50-60\% lower for CNG than for a conventional diesel bus.

The emission levels decreased steadily as the average test cycle speed was increased. This is shown in Table 5.5.

\begin{tabular}{|l|r|r|r|}
\hline \multicolumn{4}{|c|}{ Table 5.4-Some emissions data, for different test cycles (N. Clark et al.) } \\
\hline \multicolumn{1}{|c|}{ Bus Type } & $\mathbf{5 ~ m p h}$ & $\mathbf{1 0} \mathbf{~ m p h}$ & $\mathbf{1 5} \mathbf{~ m p h}$ \\
\hline Conventional Diesel & 56 & 40 & 31 \\
\hline Diesel Hybrid Electric & 32 & 22 & 10 \\
\hline CNG Bus & 15 & 11 & 7 \\
\hline
\end{tabular}

Note: The hybrid electric buses were run so as to return their batteries to the same charge state as they started.

\subsubsection{Conditions for obtaining emissions reductions from using buses}

Consider NOx emissions. Let the bus emissions be in the range of 20 to $30 \mathrm{~g} / \mathrm{mile}$ as shown in the Tables 5.3 and 5.4, and the passenger vehicle/light duty truck NOx emissions be in the range shown in Tables 4.2, 4.3, and 4.5, i.e., 0.26 to $0.36 \mathrm{~g} / \mathrm{mile}$. For this example, where all the passenger vehicles are assumed to be near term, such buses would offer no advantage in NOx emissions.

However, this is not a realistic case. It is important to consider today's actual passenger vehicle mix. The emissions as a function of average speed, obtained using the draft EPA Mobile6 model, are in Table 5.6. 
Table 5.6-Typical passenger vehicle mix emissions for 2000, obtained using the EPA's draft Mobile 6 model.

\begin{tabular}{|r|r|r|r|}
\hline \multicolumn{1}{|c|}{ Average speed mph } & \multicolumn{1}{c|}{ CO g/mile } & NOx g/mile & \multicolumn{2}{c|}{ VOC g/mile } \\
\hline 5 & 32.9 & 2.23 & 4.9 \\
\hline 15 & 18.6 & 1.54 & 2.27 \\
\hline 25 & 16.0 & 1.32 & 1.8 \\
\hline
\end{tabular}

The better diesel bus, $20.5 \mathrm{~g} / \mathrm{mile}$ NOx measured at an average speed of about $15 \mathrm{mph}$, may now be compared with the average passenger vehicle, producing $1.54 \mathrm{~g} / \mathrm{mile}$ NOx at the same speed. For this example, the bus generates fewer emissions if it replaces 14 or more passenger vehicles. Under these conditions, the use of buses, by removing passenger vehicles from the roads, should also reduce congestion on the roads, allowing higher speed and reduced emissions for the remaining passenger vehicles.

The situation would be even better if a lower emission bus were used, as required by the new EPA draft rules. Substantial advances are being made in improving diesel-powered buses, as anticipated in the new EPA draft rules. As shown in Table 5.5, the CNG bus and the hybrid electric bus are of immediate interest if certain emissions such as NOx are a primary concern. In the longer term, the fuel-cell-powered bus should offer substantial advantages.

As a final example, if a 52-seat diesel hybrid electric bus were used, it would emit less NOx at $5 \mathrm{mph}$ average speed than 14 typical cars and less NOx at $15 \mathrm{mph}$ than 7 cars. A CNG bus could be even better, but with worse fuel economy. Assuming an average of two passengers per vehicle and a full bus would take 26 cars off the road.

Of course, the passenger vehicles should also be improving. Nevertheless, in congested situations mass transit systems will continue to be important to minimizing pollution. The conclusion of this discussion is that careful analysis of replacing passenger vehicles with buses is needed for each situation to show clearly how to maximize the benefits. 


\subsection{ACKNOWLEDGEMENTS}

The authors appreciate the useful advice of Greg Reed (University of Tennessee), Ron Graves, David O'Kain, Frank Southworth, and John Storey (Oak Ridge National Laboratory), Bill Parkhurst and Niki Nicholas (Tennessee Valley Authority), Ken Cox and John Powell (Electric Transit Vehicle Institute). They also appreciate the support of Cynthia Oliphant, Director, Energy Division, Tennessee Department of Economics and Community Development. 


\subsection{REFERENCES}

Chandler, K. L., P. Norton, and N. Clarke. 1999. "Update from the NREL Alternative Fuel Transit Bus Evaluation Program.” National Renewable Energy Laboratory.

Clark, N, et al. 1999. "On-road Vehicle Emissions Workshop.” 9th Coordinated Research Council Workshop Proceedings, Vol. 1., April 19-21, 1999, San Diego CA.

Davis, S. C. 20000. “Transportation Energy Data Book," 20th Edition. Oak Ridge, TN: Oak Ridge National Laboratory Report ORNL-6959.

Davis, W.T., T. L. Miller, G. D. Reed, P. Doraiswamy, A. Tang, and P. Sanhueza. 2001. "Effect of Growth in VMT and New Emission Standards on NOx and VOC Emissions." Transportation Research Board, National Research Council, January 2001 Conference.

McGill, R. 1995. "Comparison of Relative Environmental Impacts of Alternative and Conventional Motor Fuels." IEA Alternative Motor Fuels Agreement Final Report for Annex VII.

Northeast Advanced Vehicle Consortium. 2000. "Hybrid-Electric Drive Heavy-Duty Vehicle Testing Project-Final Emissions Report." Available online at http://www.navc.org/Navc9837.pdf; accessed August 6, 2001.

Southern Appalachian Mountains Initiative (SAMI). 2000. "Interim Report.” Available online at http://www.saminet.org/reports/sami2000report.pdf, accessed August 3, 2001.

U. S. Department of Commerce. 1994. "PNGV—Partnership for a New Generation of Vehicles." Washington, D.C.

U. S. Department of Energy. 2000. "Technology Roadmap for the 21st Century Truck Program-A Government-Industry Research Partnership." Available online at http://www.osti.gov/hvt/21stcenturytruck.pdf, accessed August 3, 2001.

U. S. Environmental Protection Agency. February 10. 2000. "Control of Air Pollution from New Motor Vehicles: Tier 2 Motor Vehicle missions Standards and Gasoline Sulfur Control Requirements." Final Rule, 40 CFR Parts 80, 85, and 86.

U. S. Environmental Protection Agency. October 29, 1999. "Control of Emissions of Air Pollution from Highway Heavy-Duty Engines." Final Rule,40 CFR Parts 9 and 86.

U. S. Environmental Protection Agency. June 2, 2000. "Control of Air Pollution from New Motor Vehicles: Heavy-Duty Engine and Vehicle Standards; Highway Diesel Fuel Sulfur Control Requirements." Proposed Rule, 40 CFR Parts 69, 80, and 86.

Wang, M. 1999. “GREET 1.5-Transportation Fuel Cycle Mode.” Argonne National Laboratory Report ANL/ESD-39, Vol. 1 and Vol. 2. 